\title{
MANAJEMEN BERBASIS POROS MARITIM KABINET KERJA PEMERINTAHAN JOKOWI- JUSUF KALLA
}

\author{
Moh. Rosyid \\ Dosen STAIN Kudus
}

\begin{abstract}
The fact shows that 70 percent wide Indonesia is the sea. In geographic regions of the Unitary State of the Republic ofmainland only around 1.9 million kilo square meters, while the sovereignty of the sea consists of 3.1 million square kilometersand sea exclusive economic zone (ZEE) $2.7 \mathrm{~km}$ or 70 percent ofthe area of the archipelago in the form of the sea. The numberof large and small island as much as 17.500 island. A series of the island stretches from the east to the west as far as $6,400 \mathrm{~km}$ and almost 2,500 $\mathrm{km}$ from north to south. The potential for Coordinating Minister of Maritime law enforcement authorities recently have a work program be peneguhan maritime sovereignty, resource utilization, the infrastructure development and innovation development and maritime technology. The Program stresses that the maritime must be well managed to useful to the welfare of the people. The real form of the government in the form of maritime buildingutilization of maritime zones, treat maritime area, optimize the potential of waters environment, anticipation of evil in the seaand to optimize the performance of the national marine council. Various problems in the maritime governance circumventedAnalisis Manajemen Berbasis Poros Maritim by maintaining the sovereignty of the sea, in cooperation with the state adidaya, encouraged maritime industry, and take advantage of the waters as the lifeblood of the national economy.
\end{abstract}

Key Words: Water, Governance and welfare of the people

\section{A. Pendahuluan}

Sebutan 'tanah air' bagi Negara Kesatuan Republik Indonesia (NKRI) sudah didengar sejak masa lalu. Hal ini menandakan bahwa negeri ini terdiri dari perairan. Kedudukan perairan/ laut sebagai penghubung antar-pulau, bukan pemisah. Dengan demikian, pengelolaan maritim sudah lazim bila dilaksanakan secara optimal agar kesejahteraan rakyat terwujud. Mewujudkan kesuksesan hidup warga negara merupakan kewajiban negara memfasilitasinya. Akan tetapi, hidup yang sukses diidentikkan oleh 'mazhab' materialisme yang menjadikan kekayaan, jabatan, dan ketenaran sebagai tolok ukurnya. Dampaknya, dimensi kemanusiaan cenderung terabaikan. Akibatnya, keletihan

BISNIS, Vol. 3, No. 1, Juni 2015 
fisik karena kerja berlebih, stres, dan depresi menjadi penyakit sosial berimbas munculnya keletihan psikis.

Dengan adanya kenyataan sosial tersebut maka perlu dirumuskan hakikat kesuksesan selain meraih kekayaan (money) dan kekuasaan (power) yang sudah tidak memadahi lagi. Para motivator merumuskannya berupa empat konsep kesehatan lahir-batin (well being), ketakjuban (wonder), kearifan (wisdom), dan sikap pemberi (giving). Indikator kesuksesan terumuskan dengan terwujudnya kebermaknaan hidup dan tumbuhnya jiwa (thrive). Problem warga dunia, tidak hanya Indonesia adalah kesejahteraan yang tidak merata. Majalah Forbes mengeluarkan daftar 10 orang terkaya di Indonesia 2014. Peringkat pertama diduduki pemilik Grup Rokok Djarum Kudus yang juga pemilik Bank BCA kakak beradik Budi Hartono dan Michael Hartono. Peringkat puncak mereka duduki sejak 2009 dengan total kekayaan 16,5 miliar dolar AS setara Rp 203,3 triliun. Peringkat kedua, Susilo Wonowidjojo pemilik PT Gudang Garam Tbk dengan hartanya sebesar 8 miliar dolar AS setara Rp 96,46 triliun. Peringkat ketiga Anthoni Salim dan keluarga (Grup Salim) dengan jumlah 5,9 miliar dolar AS (Rp 70,8 triliun). Peringkat keempat Eka Tjipta Widjaja dan keluarga (Grup Sinar Mas) dengan total hartanya 5,8 miliar dolar AS setara Rp 69,6 triliun. Pering- 
kat kelima Sri Prakash Lohia (Indotama Tekstil) dengan harta sebesar 4,4 miliar dolar AS setara Rp 52,8 triliun. Peringkat keenam Chairil Tanjung (CT Corp) dengan jumlah harta 4,3 miliar dolar AS setara Rp 51,6 triliun. Peringkat ketujuh Boenjamin Setiawan dan keluarga (Kalbe Farma) sebesar 3,5 dolar AS setara Rp 42 triliun. Peringkat kedelapan Mochtar Riady dan keluarga dengan jumlah kekayaan 2,7 miliar dolar AS (Rp 28,8 triliun). Peringkat kesembilan, Peter Sondakh (Rajawali Corporation) 2,3 miliar dolar AS (Rp 2,7 miliar dolar AS setara Rp 27,6 triliun). Peringkat kesepuluh Sukanto Tanoto (Royal Golde Eagle) 2,1 miliar dolar AS setara Rp 25,2 triliun.

Di sisi lain, potret kehidupan miskin di Jakarta yang memprihatinkan dialami pengojek sepeda. Malam beranjak larut di Kali Besar Barat, Jakarta. Selasar di sebelah Toko Merah hingga dekat diskotek Athena lengang. Di balik itu, puluhan sepeda onthel kusam berdiri di samping puluhan pengemudinya yang terlelap di lantai. Sepeda dilengkapi payung, tas terpal plastik berisi pakaian, perlengkapan mandi, dan kunci baut seadanya. Mereka tinggal di Tangerang, Banten ada juga di Karawang, Jawa Barat jika ke lahan kerja ditempuh dengan sepedanya 3 jam. Kalau alat vital sudah tak terasa, berarti ia harus berhenti mengayuh. Kepulangannya seminggu sekali. Pengojek (konsumen) jumlahnya menyusut, jika tahun 1980-an penumpang mereka setiap hari bisa mencapai 20 orang. Tahun 2010, tak lebih dari 5 orang karena ada ojek sepeda motor. Sebagian besar pengojek adalah korban pembangunan bandar udara internasional (Soekarno-Hatta) yang tergusur tahun 1973. Uang ganti tanah dan rumah yang diterima menguap karena praktik calo dan teror. Sebagian pengojek adalah petani yang lahannya susut karena meluasnya pusat perbelanjaan dan perumahan. Tahun 2010, setiap hari mereka menyisihkan uang maksimal Rp 3.000, kadang tak bisa, bahkan kadang sehari hanya makan sekali. Sekarang mengumpulkan uang sehari paling banyak Rp 20.000. Buat makan tiga kali, kopi, dan rokok Rp 15.000. Buat mandi, buang air besar, dan mencuci pakaian Rp 3.000. Hari sial bagi pengojek sepeda onthel adalah jika ban sepedanya bocor (Rosyid, 2015:28).

Kemiskinan tersebut penyebab rendahnya daya beli masyarakat sehingga pemerintah perlu melakukan terobosan 
agar harga tidak melangit sehingga daya beli tergapai. Faktor lain penyebab rendahnya daya beli si miskin karena tingginya harga kebutuhan pokok. Tingginya kebutuhan pokok dikarenakan tingginya biaya distribusi bahan pokok/logistik yang melalui jalan darat persentasenya 90,34 persen, angkutan laut hanya 7 persen, angkutan sungai 1,01 persen, angkutan penyeberangan 0,98 persen, angkutan kereta 0,62 persen, dan angkutan udara hanya 0,05 persen. Angkutan logistik darat terpusat di Jawa, bahkan jalur darat pantai utara Jawa ribuan hilir mudik truk barang per hari. Untuk menyikapi hal ini, Presiden SBY berupaya membangun jalur rel ganda kereta api sepanjang $727 \mathrm{~km}$ di pantura, meski belum maksimal penggunannya. Nilai lebih angkutan truk adalah sifatnya yang door to door sehingga tidak berkali-kali bongkar barang. Presiden Jokowi mencanangkan program poros maritim yang memanfaatkan jalur laut sebagai urat nadi distribusi logistik.

Menyikapi pentingnya maritim, Menteri Koordinator Kemaritiman saat itu Indroyono Soesilo Minggu 28 Desember 2014 menyatakan, program kerja sektor kemaritiman berupa peneguhan kedaulatan maritim, pemanfaatan sumber daya, pembangunan infrastruktur, dan pengembangan inovasi dan teknologi maritim. Meneguhkan kedaulatan maritim dengan (1) menyelesaikan batas wilayah laut dengan mengoptimalkan riset dan data oseanografi. Hingga akhir 2014, Indonesia memiliki kapal riset Badan Pengkajian dan Penerapan Teknologi (BPPT), Lembaga Ilmu Pengetahuan Indonesia (LIPI), Kementerian Kelautan dan Perikanan (KKP), dan TNI AL, (2) meningkatkan kesejahteraan maritim di wilayah perbatasan dan pulau-pulau terluar Indonesia. Tahun 2015, pemerintah menyambung listrik di 47 lokasi perbatasan dan pulau-pulau terluar. Untuk keamanan dan keselamatan maritim, dibentuk Badan Keamanan Laut (Bakamla) yang mengintegrasikan sistem komando kontrol komunikasi dan informasi, sistem monitoring kapal, dan radar milik perhubungan laut, TNI AL, dan Polri. Pemanfaatan sumber daya alam hayati dan nonhayati termasuk pariwisata untuk mendorong pengendalian perikanan tangkap dan pengembangan perikanan budidaya. Untuk mendorong pariwisata bahari ditingkatkan wisatawan mancanegara dari 10 juta pada 2015 menjadi 20 juta pada 2019. Upayanya dengan 
membangun lokasi marina untuk penambatan kapal di Kupang, Ambon, Labuan Bajo, dan Tanjung Pinang. Peningkatan pembangunan infrastruktur maritim meliputi pelabuhan, kapal, dan galangan kapal. Sebanyak 24 pelabuhan dikembangkan pada 2015. Pemerintah menganggarkan tambahan tahun 2015 sebesar Rp 15,9 triliun untuk meningkatkan infrastruktur perhubungan, pelayaran, dan penerbangan perintis. Menjadi bangsa bahari melalui inovasi ilmu pengetahuan dan teknologi untuk mengembangkan budaya bahari (Kompas, 29 Desember 2014).

Dilakukan pula upaya membangun pelabuhan, mulai dari pelayaranjarak pendek (short sea shipping) sebagaimana Pelabuhan Marunda Center di Jakarta Utara, Pelabuhan Kendal di Kendal Jawa Tengah, dan Pelabuhan Paciran Surabaya. Armada kapal yang digunakan di antaranya Ferrindo S PT Angkutan Sungai Danau dan Penyeberangan (ASDP) dengan kapasitas (daya tampung) 60 truk, 20 mobil, dan 200 sepeda motor. Pemerintah mengucurkan Rp 50 miliar untuk membangun pelabuhan dan pelelangan ikan di Selat Lampa Kabupaten Natuna, Kepulauan Riau. Adapun fasilitas pendukung akan dibangun dari APBN 2016. Harapan dengan membangun pelabuhan dan pabrik es (cold storage) di Natuna agar hasil tangkapan ikan tidak dijual di tengah laut dari kapal ke kapal. Rencana serupa, pemerintah membangun di Antang, Kabupaten Anambas, Kabupaten Natuna (Kompas, 27 Desember 2014, hlm.17). Optimalnya pelabuhan dan infrastruktur tersebut, harapannya tidak terjadi tindak kriminal bagi nelayan. Sebagaimana Disertasi Tri Nuke Pudjiastuti pada Departemen Kriminologi Fakultas Ilmu Sosial dan Ilmu Politik UI berjudul Konstruksi Kejahatan terhadap Nelayan Tradisional sebagai Pelaku Penyelundupan Migran suatu Bentuk Viktimisasi Struktural dan Hegemoni Kultural yang meriset tahun 2010-2013 dipertahankan dihadapan tim penguji. Kemiskinan dan lemahnya pengawasan otoritas keamanan mendorong nelayan tradisional di Teluk Palabuhanratu, Jawa Barat, menjadi anak buah kapal atau mengantar para migran dengan tujuan Australia ke tengah laut merupakan bagian dari strategi bertahan hidup (crime accommodation). Kemungkinan dilakukannya nelayan untuk melawan kemiskinan dan timbul motivasi untuk melakukan kejahatan dengan caranya sendiri 
karena kurangnya pembinaan dan kontrol sosial di masyarakat. Perilaku kriminalnya untuk menambah penghasilan (Kompas, 15 Juli 2014).

Satu hal yang tak kalah penting dalam meningkatkan kesejahteraan nelayan adalah penerapan teknologi. Sebagaimana Kampung Nelayan Ampenan di Kabupaten Lombok Barat, Nusa Tenggara Barat sebagai wilayah percontohan penerapan aplikasi $\mathrm{m}$-Fish yang berisi aneka informasi yang dibutuhkan nelayan. Aplikasi itu diharapkan menekan biaya operasi, penanganan keadaan bahaya, dan menghalau nelayan ilegal. Informasi yang ditampilkan pada aplikasi itu adalah prakiraan cuaca, persebaran plankton, video pelatihan, harga ikan di pengepul, layanan percakapan antar-pengguna, pengiriman pesan darurat lengkap koordinat untuk melaporkan keberadaan kapal yang diduga ilegal. Aplikasi tersebut dikembangkan oleh Tone bekerja sama dengan XL Axiata sebagai penyedia jasa telekomunikasi. Bila aplikasi itu sukses, produksi ikan akan melimpah (Kompas, 28 Februari 2015).

Strategi pembangunan nasional selama ini masih sentralistis dan dominan darat. Laut dan kepulauan kecil yang sebenarnya memiliki potensi ekonomi strategis diabaikan, bahkan mengeksploitasi sumber daya kelautan dan menciptakan kesenjangan sosial ekonomi. Akibatnya, kerusakan ekosistem laut dan struktur sosial kepulauan menjadi dampak integral pembangunan itu sendiri. Meskipun fondasi hukum berupa Deklarasi Djuanda tanggal 13 Desember 1957, UU Nomor 4 Tahun 1960, PP Nomor 8 Tahun 1962, pengakuan UNCLOS 1982, dan UU Nomor 6 Tahun 1996 menegaskan bahwa Indonesia negara kepulauan dan maritim. Sejak era Presiden Gus Dur, dibentuk Kementerian Kelautan.

Naskah ini sebatas memaparkan pentingnya maritim dan upaya pemerintah membangun maritim sebagai basis perekonomian rakyat. Walaupun data naskah ini mengandalkan pemberitaan koran.

\section{B.Landasan Teori}

\section{Potensi Nusantara}

Nusantara memiliki sekitar 500 etnis yang tertebar di beberapa pulau. Etnis tersebut dikelompokkan dalam tiga kelompok 
populasi (pohon filogenetik). Kelompok pertama merupakan manusia Batak, Jawa, Tengger, Bali, Dayak, Minang, dan Melayu (Riau). Kedua, Sasak, Makassar, Bugis, Sumba Timur, Kaili, Minahasa, dan Sumbawa. Ketiga, manusia Alor dan Papua. Kelompok ketiga ini berbeda dengan kelompok pertama dan kedua karena nenek moyang kelompok ketiga yakni Aborigin Australia dan Papua lebih dulu menempati kepulauan Indonesia yakni 50.000-60.000 tahun lalu, disusul kedatangan para migran penutur Austronesia pada 5.000-2.000 tahun lalu. Tahun 2011, berdasarkan global positioning system (GPS), sebanyak 4.500 pulau dari 13.466 pulau telah terdaftar di badan PBB, United Nations Group of Experts on Geographical Names (UNGEGN). Sisanya 8.966 pulau akan didaftarkan oleh Kementerian Kelautan dan Perikanan tahun 2012. Terdapat 92 pulau kecil terluar di Indonesia, hanya 12 pulau yang dijaga TNI (Pulau Rondo, Berhala, Nipa, Sekatung, Marore, Miangas, Marampit, Fani, Fanildo, Brass, Marampit, dan Dana) yang berbatasan dengan Malaysia, Singapura, dan Filipina. Dari 92 pulau, 31 pulau berpenduduk. Tahun 2012, terdapat tambahan 16 pulau, sehingga jumlahnya menjadi 108 pulau. Jumlah 12 pulau yang terjaga TNI merupakan tugas Direktorat Jenderal Potensi Pertahanan (Ditjen Pothan) berdasarkan Peraturan Menteri Pertahanan Nomor: PER/01/M/VII/2005 meliputi menyiapkan rumusan kebijakan kementerian di bidang potensi pertahanan, menyusun standar, norma, pedoman, kriteria, prosedur di bidang potensi pertahanan, merumuskan dan melaksanakan kebijakan dan standarisasi teknis di bidang Pothan nirmiliter, dan melaksanakan kebijakan di bidang pembinaan kesadaran bela negara, potensi SDM, SDA, potensi sarana dan prasarana, dan administrasi dan manajemen Ditjen Pothan. Potensi pertahanan adalah seluruh sumber daya nasional berupa SDM, SDA, dan sumber daya buatan, nilai-nilai, teknologi, serta dana yang digunakan untuk meningkatkan kemampuan pertahanan negara. Terbatasnya jumlah personil TNI, perbandingan dengan penduduk (230 juta) sebanyak 0,17 persen. Idealnya Indonesia memiliki tentara sebanyak 4 persen atau 920 ribu personil, realitanya tahun 2012 baru memiliki 400 ribu, maka dibutuhkan tambahan tentara minimal 520 ribu Komando Cadangan yang sewaktu-waktu dapat dimobilisasi sesuai peraturan perundangan (Republika, 30 Juli 2012, hlm.2). Terbatasnya 
jumlah tentara berdampak terhadap optimalnya pengamanan wilayah Nusantara. Sebagaimana kapal dengan anak buah kapal (ABK) asing membawa ribuan ton hasil tangkapan ikan ke luar negeri, seperti Thailand, Vietnam, dan Tiongkok maka Kementerian Kelautan dan Perikanan (KKP) membenahi tata kelola dengan transparansi data perikanan pada publik sehingga dapat diawasi seluruh pemangku kepentingan. Hal ini ditopang pemberlakuan moratorium izin kapal dan penghentian alih muatan kapal di laut. Kementerian KKP akan menaikkan gaji PNS di Kementeriannya 50-100 persen karena gajinya masih rendah dibanding pegawai swasta (Kompas, 6 Desember 2014, hlm.19).

Upaya pemerintah mengoptimalkan sumber daya maritim (bahari) dilakukan dengan beragam cara. Satu di antaranya dengan menjaga kedaulatan laut. Harapannya, ikan sebagai sumber bahan makanan yang benilai tinggi gizinya dapat dikonsumsi masyarakat karena selama ini, pencurian ikan (illegal fishing) oleh nelayan asing sangat merugikan perekonomian nasional. Dampak dari penanganan penangkapan ikan secara ilegal akan menambah pasokan ikan sebanyak 1,6 juta ton. Di sisi lain, warga Indonesia masih rendah konsumsi ikannya bila dibandingkan dengan negara lain. Data Dirjen Pengolahan dan Pemasaran Hasil Perikanan (P2HP) Kementerian Kelautan dan Perikanan Saud P Hutagalung mengatakan, rata-rata konsumsi ikan masyarakat masih rendah, yakni $35 \mathrm{~kg}$ per kapita per tahun. Harapannya, menjadi $38 \mathrm{~kg}$ per kapita per tahun dan pada 2019 ditargetkan $50 \mathrm{~kg}$. Bahkan Malaysia telah mencapai $70 \mathrm{~kg}$ per kapita per tahun. Idealnya konsumsi ikan 115 gr per orang per hari, kini di Indonesia hanya $92 \mathrm{~kg}$ per orang per hari (Kompas, 1 Desember 2014). Menteri KKP mengampanyekan 'Ayo kita makan ikan' dan menggelorakan no more illegal fishing (jangan lagi ada pencurian ikan). Di sisi lain, perlunya untuk meningkatkan penerimaan negara bukan pajak (PNBP) sektor kelautan dan perikanan yang tarifnya rendah, yakni per tahun hanya Rp 300 miliar.

Sumber daya perikanan meliputi perikanan tangkap (di laut) dan perikanan budidaya (akuakultur) yang dilaksanakan di laut, perairan payau, perairan tawar, perairan umum berupa danau, waduk, dan sungai. Pada 1960, poduksi dunua hanya 1,6 juta ton, sedangkan perikanan tangkap 33,9 juta ton. Pada 2012 
meningkat menjadi 66,6 juta ton dan perikanan tangkap 91,3 juta ton. Upaya untuk mengoptimalkan akuakultur menurut Husen dengan (1) perbaikan fungsi intermediasi perbankan dan lembaga keuangan nonperbankan, (2) perbaikan infrastruktur, (3) pernaikan iklim investasi dan usaha ekonomi, dan (4) peningkatan SDM dan iptek (2015:7).

Untuk menunjukkan keseriusan penanganan panangkapan ikan secara ilegal, KKP mengadakan kerja sama dengan Pemerintah Amerika. Amerika menyerahkan dana 35 juta dollar AS untuk membantu program kemaritiman Indonesia dengan total dana bantuan 68 juta dollar AS. Badan Atmosfer dan Kelautan Nasional AS (NOAA) berada di Indonesia selama seminggu untuk membantu KKP menyediakan satelit baru untuk mendeteksi cahaya lampu perahu nelayan agar dapat memberantas nelayan asing yang melintas pada malam hari. Kerja sama juga dalam hal vokasi bagi pelajar Indonesia di sekolah tinggi perikanan. Perguruan Tinggi AS yakni University of Rhode Island, University of Mississipi, dan University of Oregon siap bekerja sama. Kerja sama juga dalam hal konservasi terumbu karang. Argumen AS untuk bekerja sama karena Indonesia melakukan konservasi untuk tuna sirip kuning yang 40 persen jumlahnya hidup di Indonesia (Kompas, 21 Januari 2015).

\section{Industri Maritim}

Industri maritim mensyaratkan tiga hal, yakni kesiapan pelabuhan, kapal, dan industri galangan kapal. Untuk mewujudkannya, dikeluarkanlah Inpres Nomor 5 Tahun 2005 tentang Pemberdayaan Industri Pelayaran Nasional. Imbasnya, data Kemenhub, populasi kapal niaga nasional meningkat mencapai 13.224 unit, dua kali lipat. Terdapat istilah pembangunan maritim dengan perikanan. Ekonomi maritim memerlukan penguatan nelayan, pengelolaan mineral, riset, wisata bahari, perkapalan, dan pelabuhan yang dibangun dalam bingkai ekonomi maritim yang berbasis pulau-pulau kecil. Pulau kecil di Indonesia mencapai 1.600 pulau yang dapat dikembangkan menjadi budidaya, pariwisata, wisata bahari, perikanan, dan penelitian. Pemerintah kembali membuka izin survei untuk benda berharga asal muatan kapal tenggelam. Lokasi kapal tenggelam di laut Indonesia akan dipetakan oleh Ditjen Kelautan Pesisir dan Pulau-Pulau 
Kecil Kemen KKP. Bila kapal yang tenggelam diangkat bisa dijadikan riset untuk kemanfaatan ekonomi dan ilmu pengetahuan. Biaya survei hingga pengangkatan oleh Panitia BMKT di Cirebon membutuhkan dana Rp 10 juta dollar AS. Menurut Ditjen Pesisir, awal Januari 2015 sudah ada izin survei dan pengangkatan di 13 lokasi yang tersebar di Laut Jawa dan Kepulauan Riau. Ada 5 lokasi dalam proses pengajuan izin, 7 dalam proses kelengkapan administrasi, dan 1 lokasi sudah terbit rekomendasi izin. Sejak 2011 pemerintah menerbitkan moratorium atau penghentian perizinan survei dan pengangkatan benda berharga asal muatan kapal tenggelam. Moratorium dihapuskan pada pada September 2014 seiring maraknya pencurian di Kepulauan Riau karena izin moratorium. Adapun wisata bahari di antaranya di Kepulauan Anambas, Pulau Pari hingga Gili Gede, Raja Ampat.

\section{Nawacita Jokowi - Jk}

Nawacita merupakan janji Calon Presiden Jokowi dan Cawapres Jusuf Kalla (2014-2019) yang tertuang dalam 9 prioritas. Visi yang diusung adalah "Terwujudnya Indonesia yang Berdaulat, Mandiri, dan Berkepribadian Berlandaskan Gotong Royong". Ke-9 janji meliputi (1) Kami akan menghadirkan kembali negara untuk melindungi segenap bangsa dan memberikan rasa aman pada seluruh warga negara, melalui pelaksanaan politik luar negeri bebas aktif, keamanan nasional yang terpercaya dan pembangunan pertahanan negara trimatra terpadu yang dilandasi kepentingan nasional dan memperkuat jati diri sebagai negara maritim, (2) Kami akan membuat pemerintah tidak absen dengan membangun tata kelola pemerintahan yang bersih, efektif, demokratis, dan terpercaya, (3) Kami akan membangun Indonesia dari pinggiran dengan memperkuat daerah-daerah dan desa dalam kerangka negara kesatuan, (4) Kami akan menolak negara lemah dengan melakukan reformasi sistem dan penegakan hukum yang bebas korupsi, bermartabat, dan terpercaya, (5) Kami akan meningkatkan kualitas hidup manusia Indonesia, melalui peningkatan kualitas pendidikan dan pelatihan dengan program Indonesia pintar wajib belajar 12 tahun bebas pungutan, (6) Kami akan meningkatkan produktivitas rakyat dan daya saing di pasar internasional, sehingga bangsa Indonesia bisa maju dan bangkit 
bersama bangsa-bangsa Asia lainnya, (7) Kami akan mewujudkan kemandirian ekonomi dengan menggerakkan sektor-sektor strategis ekonomi domestik, (8) Kami akan melakukan revolusi karakter bangsa, melalui kebijakan penataan kembali kurikulum pendidikan nasional dengan mengedepankan aspek pendidikan kewarganegaraan, dan (9) Kami akan memperteguh kebhinekaan dan memperkuat restorasi sosial Indonesia, melalui kebijakan memperkuat pendidikan kebhinekaan dan menciptakan ruang-ruang dialog antarwarga.

\section{Batas Negara}

Pemerintah RI mendeklarasikan Wawasan Nusantara pada tanggal 13 Desember 1957, dikenal dengan Deklarasi Juanda yang menetapkan kawasan perairan di bagian dalam kepulauan Indonesia otomatis menjadi bagian dari wilayah kedaulatan Indonesia. Sementara itu, ketentuan pengukuran 3 mil dari garis pantai setiap pulau diubah menjadi 12 mil. Adapun kawasan ZEE (Zona Economi Exclusive) cakupannya mencapai 200 mil dari garis pantai setiap pulau. Kewenangan ZEE sebatas mengelola dan memelihara kekayaan alam saja, sementara di wilayah 12 mil tersebut Indonesia berkedaulatan penuh di daratan, wilayah perairan, dan terhadap tanah di bawah permukaan air dan ruang udara yang ada di atasnya (sovereign rights). Pada tahun 1982 konsep Wawasan Nusantara diterima menjadi bagian konvensi hukum laut internasional hasil Konferensi PBB tentang hukum laut yang ketiga (UNCLOS) (Kompas, 29 Agustus 2010, hlm.10). Bahkan setelah subkomisi Batas Landas Kontinen (CLCS) PBB tanggal 12 s.d 17 Agustus 2010 rapat di markasnya New York menyetujui klaim Indonesia atas batas terbaru yang berada di sebelah barat Sumatera yakni wilayah perairan seluas 4 ribu $\mathrm{km}$ persegi. Klaim pengajuan tersebut sejak tahun 2008 berdasarkan Konvensi Hukum Laut tahun 1982 dan bukti secara geologis ada persamaan dasar laut antara wilayah di luar garis batas dan yang ada di dalam (Republika, 28 Agustus 2010, hlm.1). Wilayah seluas itu perlu pengelolaan yang optimal, agar potensi berupa aneka ragam hayati dan nonhayati yang ditinggalkan leluhur penuh dengan muatan sejarah dapat dikembangkan menjadi modal pembangunan nasional dan dijadikan sebagai materi pembelajaran kehidupan. 
Di laut, berbatasan dengan 10 negara (India, Malaysia, Singapura, Thailand, Vietnam, Filipina, Palau, Papua, Papua Niugini, Australia, dan Timor Lorosae) dan di darat berbatasan dengan 3 negara (Malaysia, Papua Niugini, dan Timor Lorosae). Dalam Permenhan Nomor 10 Tahun 2010 ditetapkan 12 pulau kecil terdepan yakni Pulau Rondo, Berhala, Nipa, Dana Rote, Fani, Fanildo, Sekatung, Miangas, Marore, Marampit Batek, dan Bras. Walaupun abrasi pantai di Pulau Miangas, Kab.Talaud, Sulut berlangsung selama 5 tahun terakhir. Sejumlah kawasan pesisir Pantai Miangas telah tergerus laut hingga belasan meter. Pembangunan talud Pulau Miangas sepanjang $400 \mathrm{~m}$ denga nilai proyek Rp 24 miliar sebagai langkah awal yang mendatangkan material bangunan dari Manado dengan kapal khusus. Pulau Miangas seluas 2,93 km di ujung utara Indonesia. Miangas posisinya berada di tengah gugusan Pulau Nanusa yang resisten atas abrasi dan hantaman ombak dari 4 sudut mata angin (Kompas, 23 Januari 2013). Hasil inventarisasi, terdapat 92 pulau kecil dan 12 pulau dijaga TNI. Penjagaan wilayah laut oleh TNI dengan 13 instansi menyimpan kelemahan mulai dari minimnya teknologi persenjataan dan komunikasi, kurangnya pembangunan infrastruktur yang terintegrasi, lemahnya SDM, lemahnya koordinasi, dan pembiayaan yang tinggi. Kemendagri yang mengepalai Badan Nasional Pengelola Perbatasan (BNPP) pada tahun anggaran 2011 mendapatkan pagu anggaran sebanyak Rp 700 miliar dan tahun 2010 sebesar Rp 25 miliar (Pramodawardhani, 2010:7). Forum ekonomi dunia yang dihadiri pemimpin negara, pemimpin perusahaan, akademisi, dan masyarakat sipil pada 23 Januari 2013 di Davos-Klosters, Swiss membahas masalah kunci tantangan global berupa pertumbuhan ekonomi, politik kawasan, dan hubungan antarwilayah. Hal ini menandaskan bahwa politik kawasan dan hubungan antarwilayah menjadi isu penting.

\section{Pembahasan}

\section{Pemanfaatan Zona Maritim}

Sebagai negara kepulauan, kemampuannya diwujudkan dengan karya kapal untuk berlayar antar-negara, sebagaimana kapal Pinisi. Kapal ini dibuat secara tradisional di Bulukumba, Sulawesi Selatan sejak masa silam. Ciri khasnya mempunyai dua tiang layar utama dan tujuh buah layar. Rata-rata panjang kapal 
kecil $17 \mathrm{~m}$ yang besar $25 \mathrm{~m}$, bobot $30-40$ ton, luas $33 \times 25=8,25$. Daya jelajahnya mengarungi samudera mengandalkan layar yang teruji sejak dahulu hingga kini. Pada masa lalu, wilayah yang diarungi merupakan lautan luas milik publik internasional. Akan tetapi, bangsa Indonesia diuntungkan dengan adanya Deklarasi Djuanda yang eksis sejak 13 Desember 1957. Imbasnya seluruh wilayah perairan/laut yang menghubungkan antarpulau di Indonesia menjadi wilayah Indonesia sehingga menjadi negara kepulauan terbesar di dunia. Sebelum Deklarasi Djuanda, wilayah perairan tersebut milik publik internasional sehingga kekayaan yang ada di dalamnya dapat dimanfaatkan oleh bangsa dunia. Berdasarkan Konvensi Hukum Laut Internasional 1982 menetapkan tiga alur laut kepulauan Indonesia sebagai alur pelayaran dan penerbangan oleh kapal atau pesawat udara internasional. Ketiga alur laut kepulauan Indonesia dilalui 45 persen dari total nilai perdagangan dunia. Bila pemerintah tidak sigap dengan penguasaan area perairan maka dijadikan daerah jelajah warga asing.

Zona laut untuk tata ruang laut Indonesia masih tertinggal. Penetapan batas wilayah maritim RI belum optimal. Menurut Menko Kemaritiman Indroyono Soesilo saat itu, sebanyak 40 persen wilayah perbatasan laut Indonesia dengan Negara-negara tetangga masih belum selesai. Terdiri batas teritorial (304,9 mil laut atau sekitar 564,7 km), ZEE-nya 2.258,12 mil laut atau sekitar $4.182,04 \mathrm{~km}$, dan landasan kontinentalnya 1.288,13 mil laut atau sekitar 2.385,62 km. Pemerintah menyiapkan kapal survei dan tenaga ahli untuk menyelesaikannya. Wilayah maritim RI yang belum dirundingkan berbatasan dengan Timor Leste, India, dan Thailand. Saat ini pemerintah berunding dengan Malaysia, Vietnam, Palau, Filipina, dan Singapura. Batas maritim menjadi fokus memperkuat kedaulatan maritim (Kompas, 15 Januari 2015).

Pembangunan kawasan pesisir dan laut berlandaskan pada UU Nomor 27 Tahun 2007 tentang Pengelolaan Wilayah Pesisir dan Pulau-Pulau Kecil yang telah direvisi. Zonasi laut terdiri atas zona pemanfaatan umum untuk pertumbuhan ekonomi, zona konservasi untuk keberlanjutan pesisir, dan zona alur untuk kawasan strategis nasional untuk memetakan kapasitas di pesisir, rencana pengelolaan, dan pihak mana yang 
bertanggung jawab. Luasnya area tersebut, hanya 12 pulau yang terjaga TNI atau 31 persen. Data FAO, organisasi pangan PBB menyebutkan setiap bulan potensi perikanan laut Indonesia yang tercuri mencapai Rp 30 triliun. Penelitian Dirjen Pengawasan Sumber Daya Kelautan dan Perikanan Kementerian Kelautan dan Perikanan tahun 2008 menyebutkan, di Perairan Arafuru potensi perikanan laut yang dicuri mencapai $\mathrm{Rp} 11,8$ triliun per tahun. Indonesia baru memiliki 25 kapal untuk menjaga wilayah laut, idealnya 80 kapal (Kompas, 18 Agustus 2012, hlm.21). Hal ini merupakan tugas yang dianalisis Direktorat Jenderal Potensi Pertahanan (Ditjen Pothan) berdasarkan Peraturan Menteri Pertahanan Nomor PER/01/M/VII/2005 meliputi menyiapkan rumusan kebijakan kementerian di bidang potensi pertahanan, menyusun standar, norma, pedoman, kriteria, prosedur di bidang potensi pertahanan, merumuskan dan melaksanakan kebijakan dan standarisasi teknis di bidang Pothan nirmiliter, dan melaksanakan kebijakan di bidang pembinaan kesadaran bela negara, potensi SDM, SDA, potensi sarana dan prasarana, dan administrasi dan manajemen Ditjen Pothan. Potensi pertahanan adalah seluruh sumber daya nasional berupa SDM, SDA, dan sumber daya buatan, nilai-nilai, teknologi, serta dana yang digunakan untuk meningkatkan kemampuan pertahanan negara. Terbatasnya jumlah personil TNI, perbandingan dengan penduduk (230 juta) sebanyak 0,17 persen. Idealnya Indonesia memiliki tentara sebanyak 4 persen atau 920 ribu personil, realitanya tahun 2012 baru memiliki 400 ribu, maka dibutuhkan tambahan tentara minimal 520 ribu Komando Cadangan yang sewaktu-waktu dapat dimobilisasi sesuai peraturan perundangan (Republika, 30 Juli 2012).

\section{Merawat Area Perairan}

Pada tahun 2014 total area konservasi perairan nasional sekitar 15,5 juta hektar. KKP menargetkan area konservasi perairan pada 2020 mencapai 20 juta ha. Tahun 2015 KKP menambah luas kawasan konservasi baru minimal seluas 50.000 ha. KKP dalam mewujudkan kebijakan pengelolaan perikanan berkelanjutan dengan melarang menangkap ikan di laut yang jaraknya di bawah 4 mil laut atau sekitar 7,4 $\mathrm{km}$ dari pantai. KKP juga membatasi penangkapan lobster, kepiting, dan 
rajungan yang dalam kondisi bertelur dan dibatasi ukuran yang ditangkap. Hal ini tertuang dalam Permen Nomor 1 Tahun 2015 tentang Penangkapan Lobster (Panulirus spp), Kepiting (Scylla $s p p$ ), dan Rajungan (Portunus pelagicus spp) tanggal 6 Januari 2015. Peraturan memperbolehkan penangkapan lobster panjang karapas di atas $8 \mathrm{~cm}$, kepiting lebar karapas di atas $15 \mathrm{~cm}$, dan rajungan lebar karapas di atas $10 \mathrm{~cm}$. Hal ini bertujuan demi keberlanjutan populasinya di alam. Argumen Kementerian KKP, kecenderungan di sejumlah daerah, ukuran hasil tangkap ketiga spesies itu dari alam kian menurun karena yang ditangkap masih berumur belia. Juga memberi kesempatan spesies berkembang biak. Lobster matang gonad (usia reproduksi) umur 7-8 bulan dengan masa hidup 8 tahun. Kepiting matang gonad 6 bulan bermasa hidup 2-3 tahun, rajungan matang gonad 3-4 bulan bermasa hidup 2-3 tahun. Berdasarkan data Balitbang KKP, penangkapan lobster berlebih di Laut Hindia barat, Laut Natuna, Laut Tiongkok Selatan, Laut Pasifik (utara Papua), Laut Arafura, Laut Jawa, dan Hindia bagian timur. Data Direktur Sumber Daya Ikan KKP, potensi lobster 7.790 ton per tahun. Penangkapan tahun 2013 mencapai 16.709 ton per tahun. Untuk kepiting, ditangkap 33.227 ton per tahun. Produksinya turun 2 persen, potensi belum diketahui. Adapun produksi rajungan 52.399 ton per tahun. Ketiga spesies itu tak masuk kategori satwa endemik terancam punah. Namun keberlanjutan di alam kian tertekan (Kompas, 20 Januari 2015). Penolakan atas Permen KKP yang melarang ekspor lobster ukuran di bawah 8 $\mathrm{cm}$ dan pembatasan penangkapan kepiting terjadi di Tegal Jawa Tengah, Sumbar, NTB, dan Kaltim. Adapun nelayan di Tegal juga menolak pelarangan penggunaan alat tangkap ikan jenis trawl (Kompas, 21 Januari 2015).

Luas wilayah bila tidak dirawat muncul dampak negatif, sebagaimana sejumlah pulau di sekitar Batam dan Bintan, Kepulauan Riau yang rawan tenggelam akibat abrasi dan penambangan bauksit, begitu pula pulau di Natuna dan Anambas. Di sekitar Bintan, terancam tenggelam karena abrasi yakni Pulau Sentot di utara Bintan luasnya 2 hektar hanya berupa pasir, sebagai pulau terdepan dan penting untuk menetapkan perbatasan negara. Adapun Pulau Tembora dan Pulau Ngalih di selatan Bintan terancam penambangan bauksit. Pulau tersebut 
kurang dari 80 hektar. Di Batam, terdapat 8 pulau terancam hilang karena abrasi, seperti Pulau Putri, Pulau Batu Berantai di utara Batam dan pulau Sentot merupakan pulau terdepan. Diprediksi 10 tahun ke depan, 120 pulau di Kepulauan Riau terancam hilang akibat kenaikan permukaan air laut paling rendah 3 milimeter per tahun yang merusak pesisir dengan ketinggian hingga 0,6 meter dan terjadinya abrasi (Kompas, 29 Januari 2013). Abrasi pantai di Pulau Miangas, Kabupaten Talaud, Sulawesi Utara berlangsung selama 5 tahun terakhir. Sejumlah kawasan pesisir Pantai Miangas telah tergerus laut hingga belasan meter. Pembangunan talud Pulau Miangas sepanjang $400 \mathrm{~m}$ dengan nilai proyek Rp 24 miliar sebagai langkah awal yang mendatangkan material bangunan dari Manado dengan kapal khusus. Pulau Miangas seluas 2,93 km di ujung utara Indonesia. Miangas posisinya berada di tengah gugusan Pulau Nanusa yang resisten atas abrasi dan hantaman ombak dari 4 sudut mata angin (Kompas, 23 Januari 2013). Bahkan sengketa perbatasan laut pada Senin, 3 Februari 2014 di perbatasan laut antara warga Desa Mesiang dan Desa Gomo-Gomo di Kecamatan Aru Tengah Selatan, Kabupaten Kepulauan Aru, Maluku menyebabkan 1 tewas, 2 luka, dan penganiayaan antar-warga karena lokasi yang disengketakan tak memiliki batas secara hokum dan diklaim kedua warga desa. Potensi wilayah yang disengketakan memproduksi teripang (Kompas, 5 Februari 2014).

Perubahan ekosistem Laguna Segara Anakan yang memisahkan daratan Pulau Jawa dengan Nusakambangan di Kabupaten Cilacap Jawa Tengah terjadi. Hal ini akibat gangguan eksosistem mencakup sekitar 20 persen areal pulau yang dipicu perubahan fungsi hutan lindung. Pulau seluas 12.106 ha berubah karena perubahan pemanfaatan lahan yang semula hutan lindung jenis hutan tropis terbesar di Jawa menjadi area lahan tanaman budidaya karena pembukaan lahan kawasan hutan lindung. Terjadi pula pembalakan liar mencapai 12.480 batang per tahun oleh perdagangan illegal. Digunakan pula pemukiman liar yang pada 2014 hanya 50 keluarga tapi pada Januari 2015 mencapai 225 keluarga. Padahal, tsunami di Laut Selatan pada 2006, pulau Segara Anakan sebagai tameng warga Cilacap dari gelombang laut (Kompas, 9 Januari 2015). Akibat lanjutannya, menyebabkan populasi puluhan jenis ikan di kawasan perairan 
tersebut semakin langka. Salah satu yang terancam punah adalah ikan sidat (Anguilla sp) yang mempunyai nilai ekonomi sangat tinggi dan banyak dibutuhkan restoran Jepang per $\mathrm{kg}$ harganya Rp 100.000. Menurut Manajer Lembaga Penelitian Pengembangan Sumber Daya Lingkungan Hidup (LPPSH) Cilacap Adi Wahyono, sekitar 45 jenis ikan habitat asli Segara Anakan terancam punah akibat eksploitasi dan pendangkalan di Segara Anakan. Data Dinas Kelautan, Perikanan, dan Pengelola Sumber Daya Kawasan Segara Anakan (DKP2SDKSA) Cilacap menyebutkan, selama 100 tahun, sebanyak 90 persen kawasan Segara Anakan berubah menjadi daratan. Pada 1984 luas perairan 2.905 ha, akhir 2014 tersisa 400 ha yang dipicu pendangkalan sekitar 1 juta meter kubik per tahun dari aliran Sungai Citandui dan Cibeurem. Pada musim hujan, sedimentasi lumpur mencapai 12.000 meter kubik per hari. Pada 1970-an, hanya ada 5 pulau di tengah Segara Anakan, akhir 2014 sduah 12 pulau. Akibatnya, ikan seperti sidat laut terdesak dan sulit berkembang. Penelitian Science for the Protection of Indonesian Coastal Marine Ecosystems (Spice) bersama sejumlah perguruan tinggi nasional mencatat, sedikitnya 7.000 ha hutan bakau di sekitar Nusakambangan hancur dalam 30 tahun. Pada 1984 luas area bakau 15.000 ha, akhir 2014 tersisa 8.000 ha. Mengatasi hal tersebut, DKP2SDKSA Cilacap membagi zona konservasi, ekowisata, pertahanan, dan perkotaan (Kompas, 12 Januari 2015, hlm.14). Pemanfaatan tata ruang Laguna Segara Anakan belum memiliki landasan aturan yang jelas yang berakibat kerusakan kian parah. Menurut Kepala Dinas Kelautan, Perikanan, dan Pengelolaan Sumber Daya Kawasan Segara Anakan Cilacap Sudjiman, pemangku kepentingan terkait Segara Anakan memahami bahwa kerusakan tersebut persoalan nasional, tapi belum ada langkah efektif mengurangi kerusakan. Sedimentasi Sungai Citanduy, Cimeneng, Cibeureum, dan Cikondo di Segara Anakan tercatat 1 juta meter kubik per tahun. Kerusakan ekosistem dengan menyusutnya luas hutan akau dari 15.000 ha pada 1980-an menjadi 8.000 ha, kedalaman Laguna kini hanya 1-1,5 m. Berdasarkan PP Nomor 26 Tahun 2008, Laguna Segara Anakan sebagai Kawasan Strategis Nasional meliputi Pangandaran-Kalipuncang-Segara Anakan-Nusakambangan. Tahun 2004 pengerukan seluas 425 ha berkedalaman 1,75 m, 
pada 2008 posisinya kembali dangkal seperti semula (Kompas, 15 Januari 2015).

Dalam aspek lain, menurut Eko Sugiharto Peneliti Pusat Studi Lingkungan Hidup UGM Yogyakarta menyatakan, Pemkab Bantul DI Yogyakarta didesak melindungi kawasan gumuk atau bukit pasir di wilayah pesisir selatan dengan menetapkannya sebagai area konservasi agar perusaknya bisa dikenai sanksi. Gumuk pasir di kawasan Parangtritis merupakan fenomena alam yang terbentuk sejak ribuan tahun lalu. Pasir itu berasal dari material vulkanik Gunung Merapi yang mengalir ke beberapa sungai lalu terbawa sampai laut selatan. Karena ada ombak dan angin, pasir di laut kemudian terbawa ke pantai dan wilayah sekitarnya membentuk bukit-bukit dalam beragam bentuk. Keberadaan gumuk pasir di Parangtritis untuk menjaga keseimbangan eksosistem di wilayah pesisir. Jika gumuk pasir rusak, wilayah pesisir akan mudah terkena abrasi atau pengikisan daratan pantai karena gelomang air laut. Gumuk pasir itu semula 500 ha, akan tetapi pada 2012-2013 tersisa 45 ha kerusakan akibat pemangunan rumah, pembuatan tambak udang, dan kegiatan pariwisata (Kompas, 13 Januari 2015). Pasal 28 UU Nomor 27 Tahun 2007 tentang Pengelolaan Wilayah Pesisir dan Pulau-Pulau Terkecil menyatakan, eksosistem pesisir yang unik, misalnya gumuk pasir, bisa dilindungi dengan menetapkannya menjadi kawasan konservasi. Perda Nomor 4 Tahun 2011 tentang Rencaa Tata Ruang dan Wilayah (RTRW) Kabupaten Bantul Pasal 65 gumuk pasir di Parangtritis ditetapkan sebagai kawasan strategis lingkungan hidup.

\section{Optimalisasi Potensi Lingkungan Perairan}

Fakta menunjukkan bahwa 70 persen luas Indonesia adalah laut. Kita juga sering menyebut negeri ini negeri maritim dan bangsa bahari. Secara geografis wilayah NKRI yang berupa daratan hanya sekitar 1,9 juta kilo meter persegi, sedangkan kedaulatan laut terdiri 3,1 juta $\mathrm{km}$ persegi dan zona laut ekonomi eksklusif (ZEE) 2,7 km atau 70 persen wilayah Nusantara berupa laut. ZEE diperjuangkan sejak 1958 dan diratifikasi serta diberlakukan pada 1994. Ditambah jumlah pulau besar dan kecil sebanyak 17.500 pulau. Rangkaian pulau tersebut terbentang dari timur ke barat sejauh $6.400 \mathrm{~km}$ dan hampir $2.500 \mathrm{~km}$ dari 
utara ke selatan. Garis terluar yang mengelilingi wilayah RI sepanjang 81 ribu $\mathrm{km}$ dan 70 persennya berupa laut. Sehingga kita mempunyai suku yang hidup dan kehidupannya di laut dengan nama Orang Suku Laut berada di Kampung Pang Long dan Suku Duane di Tanjung Batu, Pulau Kundur, Kepulauan Riau. Pada awal 2013 tersisa 40 KK. Kehadiran Orang Suku Laut (OSL) di perairan direkam oleh pelancong dari China Wang Da Yuan pada abad ke-14 bahwa OSL hidup di sekitar Selat Gigi Naga, kini dikenal Selat Singapura menjadi bajak laut. Bahkan sejarawan Arab mencatat keberadaan OSL pada abad ke-9 hidup di kawasan Laut Natuna hingga Selat Singapura yang berperan sebagai prajurit laut Kerajaan Sriwijaya dan Malaka. Masa kini orang laut mengaku menjadi orang darat ada yang masih eksis dari Suku Duane di Tanjung Batu, Pulau Kundur. Berbeda dengan OSL dulu kala yang di darat manakala mencari air tawar, memperbaiki perahu atau berlindung dari angin kencang (Kompas, 23 Februari 2013).

Potensi alam kita yakni luas daratan 1,9 juta km persegi, luas perairan 3,1 juta $\mathrm{km}$ persegi, panjang garis pantai mencapai 81 ribu km dengan jumlah pulau mencapai lebih dari 17.500 pulau, laut yang dikitari 17.504 pulau dan dijaga 92 pulau terluar, berada di antara dua samudra (Laut Jawa dan Hindia) dan dua benua (Asia dan Australia), berbatasan dengan setidaknya 10 negara mulai dari Malaysia, Singapura, Thailand, Vietnam, Filipina, Australia, Papua Niugini, Timor Leste, Palau, hingga India. Dari 17.504 pulau yang sudah diberi nama 13.466 pulau dan dilaporkan pada PBB. Dari jumlah itu, sekitar 10.000 pulau kecil dan belum berpenghuni. Tim Nasional Pembakuan Nama Rupabumi, sejak tahun 2007 hingga akhir tahun 2010 menunjukkan bahwa jumlah pulau di Indonesia sebanyak 13.466 pulau (meski masih laporan sementara) berdasarkan inventarisasi dan verifikasi nama-nama pulau yang dilakukan tim dan koordinat yang diperoleh untuk tiap pulau. Sebelum diverifikasi, jumlah pulau sebanyak 17.508 pulau. Definisi pulau menurut PBB adalah obyek yang masih tampak saat air laut pasang. Untuk penamaan pulau dilakukan dengan ketentuan mengambil nama lokal yang diakui masyarakat setempat, nama pulau disebutkan dalam cerita rakyat, dan tercatat dalam peta lama atau arsip. Daftar nama pulau dilaporkan dalam 
sidang UNGEGN di Vienna, Austria pada 2 s.d 6 Mei 2011 oleh Direktorat Wilayah Administrasi dan Perbatasan, Kemendagri RI, berdasarkan PP Nomor 112 Tahun 2006. Indonesia pada tahun 1987 melaporkan pada Konferensi PBB sebanyak 17.508 pulau (Kompas, 8 April 2011).

Keberadaan pulau kecil dan terdepan di Indonesia dimanfaatkan untuk investasi yang dipimpin Dirjen Kelautan, Pesisir, dan Pulau-Pulau Kecil, Kementerian Kelautan dan Perikanan. Tahun 2010, Pulau Anak Sambu dan Pulau Nipa di Kepulauan Riau untuk investasi logistik BBM, Pulau Tabuhan di Jawa Timur dimanfaatkan untuk wisata bahari oleh investor asal Maldives, Pulau Bawal di Kalbar untuk usaha kelapa sawit, Pulau Miang Besar di Kaltim untuk pelabuhan batu bara, Kepulauan Karimata di Kalbar dan Pulau Langala di Sulawesi Tengah. Tahun 2011, lima pulau siap untuk investasi yakni Pulau Putri Barat, Pulau Putri Timur di Kepulauan Seribu untuk wisata bahari, Pulau Jukung di Kepulauan Seribu untuk budidaya laut, Pulau Ketawai di Kabupaten Bangka Tengah untuk wisata bahari dengan nilai investasi Rp 110 miliar, dan Pulau Bebuan di Kabupaten Bangka Tengah untuk investasi keramba jaring apung (Kompas, 8 April 2011).

Direktur Pendayagunaan Pulau-Pulau Kecil Kementerian Kelautan menawarkan 100 pulau kecil dari 300 yang teridentifikasi untuk dimanfaatkan investor berjangka waktu 30 tahun dan dapat diperpanjang agar terwujud pertumbuhan ekonomi dan kesejahteraan masyarakat di pulau kecil. Pulau itu memenuhi aksesibilitas, terumbu karang dalam kondisi bagus, dan sumber daya manusia. Hal ini mengacu pada UU Nomor1 Tahun 2014 tentang Perubahan atas UU Nomor 27 Tahun 2007 tentang Pengelolaan Wilayah Pesisir dan Pulau-Pulau Kecil. Hingga kini terealisasi 5 pulau dan yang dalam penjajakan 6 pulau. Penawaran pulau tertuang dalam RJMN 2014-2019 dengan target 25 pulau. Setiap tahun investasi baru pulau kecil ditarjet minimal Rp 2 triliun dengan kontribusi terhadap penerimaan negara bukan pajak minimal Rp 2 miliar. Dari total 17.504 pulau di Indonesia, jumlah pulau kecil terluar sebanyak 92 pulau. Pulau yang ditawarkan adalah Kepulauan Natuna, Kepulauan Anambas, Pulau Nipa (Batam), Gugus Pulau Pari dan Kepulauan Seribu (DKI Jakarta), Pulau Liwungan (Pandeglang Banten), 
Pulau Paserang (Sumbawa Barat, NTB), Pulau Gili Nanggu dan Pulau Gili Gede (Lombok Barat), Pulau Keramat, Pulau Bedil, dan Pulau Temudong (Sumbawa). Investasi tersebut harus memenuhi persyaratan: berbadan hukum berupa perseroan terbatas, menjamin akses publik, tak berpenduduk, belum dimanfaatkan oleh penduduk lokal, bekerja sama dengan peserta Indonesia, melakukan pengalihan saham secara bertahap kepada peserta Indonesia, melakukan alih teknologi, memperhatikan aspek ekologi, sosial, ekonomi pada luasan lahan. Pulau yang telah dibuka untuk investasi (2010-2014) yakni Pulau Bangka Kabupaten Minahasa Utara, Sulut; Pulau Anak Sambu dan Nipa, Kota Batam Kepulauan Riau; Gugus Pulau Gili Balu Kabupaten Sumbawa Barat NTB; Pulau Gili Sunut dn Pulau Gili Lawang di Kabupaten Lombok Timur; Pulau Bawah Kabupaten Kepulauan Anambas Kepulauan Riau; Pulau Nusakambangan Kabupaten Cilacap; Pulau Tabuhan Kabupaten Banyuwangi; Pulau Bawal Kabupaten Ketapang Kalbar; Pulau Ketawai Kabupaten Bangka Tengah Babel; Pulau Macaroni Kandur dan Soloinak Sumbar; Pulau Karimata Kalbar; Pulau Samalona Laelae dan Kondingaren Keke Sulsel; Pulau Gangga Kabupaten Minahasa Utara Sulut (Kompas, 16 April 2015).

Penelusuran Koalisi Rakyat untuk Keadilan Perikanan (Kiara) mengingatkan pemerintah jangan gampang mengundang asing berinvestasi di pulau kecil untuk menggenjot penerimaan negara bukan pajak yang tanpa pengawasan menyebabkan masyarakat tergusur. Pulau Gili Sunut diinvestasi perusahaan asal Singapura berdampak ditinggalkannya penduduk. Mulai tahun 2009, sebanyak 109 kepala keluarga yang berdomisili dan hidup turun-temurun di pulau kecil di Lombok Timur dipindah investor dengan uang ganti hanya Rp 3 juta per keluarga. Menurut Ketua Umum Kesatuan Nelayan Tradisional Indonesia Riza Damanik, investasi itu berdampak tak ada ruang tersisa bagi ekonomi rakyat. Seharusnya BUMN, BUMD, koperasi menjadi tuan rumah (Kompas, 18 April 2015).

Menteri KKP menyatakan, rencana investasi pulau kecil tersebut memerlukan regulasi dan menjamin keberlanjutan sumber daya ikan dan kemakmuran rakyat. Model investasi sebaiknya dibatasi pada wisata dan perikanan yang ramah lingkungan. Investasi asing tak boleh mengarah pada usaha perikanan tang- 
kap dan pengelolaan pulau oleh asing hanya bersifay menyewa. Dalam Rencana Pembangunan Jangka Menengah Nasional 20142019 pemerintah menargetkan investasi pulau kecil minimal Rp 2 triliun oertahun dengan kontribusi penerimaan negera bukan pajak minimal Rp 2 miliar per tahun (Kompas, 20 April 2015).

Wilayah Nusantara berbatasan dengan negara 'Pasifik Selatan' yang berbentuk kepulauan kecil. Bila dilihat dalam peta, hanya berupa titik seperti Kepulauan Cook, Fiji, Kiribati, Kepulauan Marshall, Micronesia, Nauru, Niue, Palau, Papua Niugini, Samoa, Kepulauan Solomon, Tonga, Tuvalu, dan Teritori Amerika Serikat (Samoa Amerika, Guam, Kepulauan Mariana Utara), termasuk Australia, Selandia Baru, dan Timor Leste. Negara dan Kepulauan tersebut dapat dijadikan mitraekonomi dan lainnya, terutama di bidang maritim.

Solusi Kementerian Kelautan dan Perikanan dalam mengatasi ancaman defisit ikan tahun 2014 berupa (i) (menjajaki) pembentukan badan sejenis Bulog untuk perikanan yang diharapkan dapat menjaga stabilitas harga dan pasokan, (ii) mengembangkan pasar elektronik (e-pasar) agar pasar ikan tak terpusat di satu wilayah sehingga produsen dan konsumen antarpulau bisa berinteraksi dan harga menjadi transparan. Hal itu harus didukung ketersediaan gudang dingin penyimpan ikan di daerah surplus ikan. Tahun 2011 e-pasar diterapkan di Muara Baru dan Muara Angke untuk ikan tongkol, tuna, dan cakalang. Saran dari Sekretaris Eksekutif Pusat Kajian Sumber Daya Pesisir dan Lautan IPB, Lucky Adrianto, keberadaan Bulog perikanan untuk menampung stok ikan akan terganjal karena komoditasnya tak tahan lama, sebaiknya diawali dengan pemetaan kebutuhan riil konsumsi ikan untuk menentukan keseimbangan pasar dan membenahi infrastruktur antarpulau dan mekanisme distribusi (Dinyatakan Sekditjen Pengolahan dan Pemasaran Hasil Perikanan Kementerian Kelautan dan Perikanan, Victor Nikijuluw (Kompas, 16 November 2010).

Rencana strategis Kementerian Kelautan dan Perikanan (KKP) 2010-2014 memproyeksikan, produksi ikan nasional, tangkap atau budi daya pada tahun 2014 mencapai 22,54 juta ton, dengan asumsi konsumsi ikan 38,67 kg per kapita per tahun sehingga terdapat defisit ikan 11,15 juta ton. Diperkirakan pada tahun 2014 terdapat 18 provinsi yang defisit pasokan ikan seper- 
ti Jawa Barat produksi ikannya 1,63 juta ton, kebutuhannya 4,06 juta ton sehingga defisit 2,43 juta ton ikan. Sebanyak 15 provinsi kelebihan produksi ikan seperti NTT, Sulawesi Tenggara, NTB, Sulsel, Sulteng, Sulut, Gorontalo, Jateng, DIY, Maluku, Sulbar, Sumsel, Malut, Sumbar, dan Papua Barat. Pada tahun 2010 pada triwulan I impor produk perikanan sebanyak 77 juta dollar AS, naik menjadi 32 persen dibandingkan dengan tahun 2009 yakni 58 juta dollar AS. Menurut Kepala Riset Pusat Kajian Pembangunan Kelautan dan Peradaban Maritim, Suhana, menyarankan agar pemerintah menjaga terpenuhinya kebutuhan ikan dalam negeri dan perlu memetakan produksi dan pemasaran produk nasional, menata distribusi produk perikanan antarpulau dan menyediakan infrastruktur perdagangan produk ikan antarpulau, memperkuat nelayan dan pengusaha perikanan agar melebarkan wilayah tangkapannya ke wilayah zona ekonomi eksklusif (ZEE) Indonesia dan laut lepas, dan jaminan pemasaran produk perikanan ke luar negeri hanya bila produksi dan pasokan dalam negeri mencapai kebutuhan nasional. Saat ini daya saing nelayan Indonesia relatif rendah, sekitar 90 persen nelayan menggunakan kapal kecil berbobot mati di bawah 30 gross ton (GT) dan perikanan budi daya terkendala permodalan dan mahalnya harga pakan. Satu hal yang mencengangkan, pemerintah pada tahun 2011 akan menghapus subsidi BBM untuk kapal nelayan berbobot lebih dari 60 GT (Kompas, 15 November 2010).

\section{Kinerja Dewan Kelautan Indonesia}

Sekretaris Dewan Kelautan Indonesia (Dekin) Dedy H Sutrisna pada Jumat 28 November 2014 mendorong pemerintah membentuk tata ruang laut nasional serta pembentukan perda rencana zona wilayah pesisir dan pulau-pulau kecil. Usulan ini berdasarkan UU Nomor 32 Tahun 2014 tentang Kelautan. Selama ini masih banyak perda yang belum disusun terkait zonasi pesisir dan pulau-pulau kecil dan tumpang tindihnya kebijakan. Persoalan yang timbul datang dari daerah. Perda zonasi yang belum dibuat menyebabkan tumpang-tindih dalam pengelolaan dan pemanfaatan wilayah dan pencaplokan pulaupulau, meski usulan ini ditolak Menteri Kelautan dan Perikanan karena UU otonomi wilayah hanya untuk daratan, tidak ada pembagian wilayah administrasi kelautan yang menimbulkan 
tumpang tindih perizinan perikanan pada tingkat provinsi. Selama ini, izin kapal berukuran hingga 30 GT diterbitkan oleh tingkat provinsi sampai jelajah 12 mil. Menteri mengharap kewenangan perizinan dikelola pemerintah pusat. Menurut pakar hukum laut internasional Hasyim Djalal, laut tak perlu diotonomisasi (Kompas, 29 November 2014). Membicarakan laut, ratusan nelayan Jawa Tengah bertemu di Kantor Dinas Kelautan dan Perikanan Jawa Tengah Senin 1 Desember 2014 menelurkan sembilan poin masalah (1) penyederhanaan pengalihan dokumen perizinan kapal nelayan dari Kemenhub ke Kemen KKP, (2) merevisi peraturan Menteri KKP Nomor 57 Tahun 2014, (3) nelayan meminta izin penggunaan alat tangkap cantrang (dogol), (4) nelayan Moro Demak, Demak Jawa Tengah mengeluhkan pendangkalan di muara sungai, (5) cabut izin pembuangan limbah industri ke laut, (6) tambah kuota nelayan Jateng, (7) diperbolehkan membeli solar di semua SPBN, (8) ada persamaan cara menghitung kebutuhan BBM antara pertamina dengan nelayan, dan (9) kuota BBM per bulan tidak bergantung musim tangkap (Suara Merdeka, 2 Desember 2014). Hal ini perlu dikawal kinerjanya agar kesejahteraan masyarakat dan nelayan terwujud. Menurut Suprayoga, ke-9 poin tersebut yang krusial adalah persoalan nomor 3, mengapa? Jaring cantrang dimodifikasi oleh nelayan agar terhindar dari Kepres Nomor 39 Tahun 1980 tentang Pelarangan Pengoperasian Trawl dengan modifikasi dan setiap daerah memiliki ragam nama, misalnya dogol, pukat tepi, otok, trawl mini, payang alit, sondong sambo, lampara dasar, jaring arat, dan cantrang. Dilarangnya trawl karena menghancurkan sumber daya perikanan, tetapi pemerintah mengizinkan trawl/ cantrang yang dituangkan dalam Permen Kelautan Nomor 06/ Men/2008 tentang Penggunaan Alat Penangkapan Ikan Pukat Hela di Perairan Kalimantan Timur Bagian Utara, yang dijadikan upaya membendung aksi kapal-kapal asing yang menggunakan trawl. Solusi mengatasi antara pelarangan dan pemberian izin (1) kapal cantrang hanya dioperasikan oleh nelayan tradisional, bukan nelayan modern, (2) pengoperasiannya hanya zona tertentu dan harus memperhatikan aspek konservasi, (3) pemerintah pusat memiliki pedoman yang jelas bagi pemda dalam mengatur pengoperasionalan kapal cantrang, baik yang menyangkut zonasi, ketentuan ukuran mata jaring, waktu 
penangkapan, pengawasan dan penegakan hukum, (4) daerah diminta membantu rencana pengelolaan sumber daya perikanan sehingga permintaan izin pengoperasian cantrang akan terkait dengan desain pengelolaan secara utuh, dan bukan sesuatu yang parsial (2014:7).

Penggunaan jaring bondet/cantrang di perairan Tayu oleh nelayan Dukuh Seti Kabupaten Pati didesak untuk dihentikan oleh nelayan Tayu dengan Kelompok Masyarakat Pengawas (Pokmaswas) Perikanan setempat. Para nelayan karena tidak berwenang menangkap, mereka melaporkan pada Polair, Kamla TNI AL, dan Dinas Kelautan dan Perikanan Kab.Pati agar proses hukum dilaksanakan. Aturan pelarangan berdasarkan UU Nomor 45 Tahun 2009 tentang Perubahan Atas UU Nomor 31 Tahun 2004 tentang Perikanan dan Peraturan Menteri KKP Nomor 18/Permen-Kp/2013 tentang Perubahan atas Permen KKP Nomor 02/Men/2011 tentang Jalur Penangkapan Ikan dan Penempatan Alat Penangkapan Ikan di Wilayah Pengelolaan Perikanan RI. Pasal 9 (1) UU Nomor 45 Tahun 2009 menyebutkan, setiap orang dilarang memiliki, menguasai, membawa, dan/atau menggunakan alat penangkapan dan/atau alat bantu penangkapan ikan yang menggunakan dan merusak keberlanjutan sumber daya ikan di wilayah pengelolaan perikanan negara RI (Suara Merdeka, 5 Januari 2015).

Dinamika tersebut, KKP menerbitkan Peraturan Menteri Nomor 2/Permen-KP/2015 tentang larangan penggunaan alat tangkap ikan pukat hela (trawl) dan pukat tarik (seine nets) di seluruh wilayah pengelolaan perikanan Indonesia. Pukat yang dilarang yakni pukat hela dasar, pertengahan, pukat udang, pukat dorong, pukat pertengahan dua kapal (pair trawl). Adapun pukat tarik yang dilarang yakni dogol (danish seines), payang, pair seines, cantrang, dan lampara dasar. Sebelumnya pemerintah menerbitkan Kepres Nomor 39 Tahun 1980 tentang Penghapusan Jaring Trawl (Pukat Harimau) di Perairan Jawa, Sumatera, dan Bali. Pukat menjadi faktor penyebab sumber daya ikan menurun dan mengancam kelestarian lingkungan sumber daya ikan. Sebagian besar pukat digunakan di Laut Arafura dan nelayan kecil sehingga terjadi konflik. Selama ini pemerintah menerbitkan izin pukat di atas 30 gros ton 
berdasarkan data potensi yang memungkinkan di Laut Arafura dan Laut Tiongkok Selatan. Namun di daerah dimodifikasi dan diberi izin pemda (Kompas, 16 Januari 2015). Laut Arafuru termasuk di dalamnya Laut Aru dan wilayah sebelah barat Laut Timor memiliki potensi sumber daya laut yang besar. Jumlah kapal ikan yang beroperasi di Laut Arafuru hingga akhir 2014 mencapai 1.200 kapal tangkap. Sejak ekspedisi Baruna pada 1964, Laut Arafuru memiliki potensi khususnya udang dan ikan yang melimpah. Tercatat ada 500 jenis ikan dan 400 jenis krustasea, hewan laut seperti lobster, teripang, bulu babi, dan cumi-cumi yang mencapai 855,5 ton per tahun. Dengan demikian, perlunya mempercepat pengelolaan Perikanan Laut Arafura dengan tujuan (1) mewujudkan pengelolaan sumber daya ikan dan habitatnya secara berkelanjutan, (2) meningkatnya manfaat ekonomi dari perikanan berkelanjutan untuk menjamin kesempatan kerja dan pengurangan kemiskinan, dan (3) meningkatkan partisipasi dalam memberantas kegiatan illegal fishing (Syahailatua, 2015:7).

Agar potensi maritim Nusantara tidak dimanfaatkan oleh oknum yang hanya untuk memperkaya diri dengan cara yang absah, Pusat Pelaporan dan Analisis Transaksi Keuangan (PPATK) dan Kementerian Keuangan bekerjasama untuk mengungkap praktik pencurian ikan yang diduga dilakukan korporasi dan oknum aparat. PPATK akan menelusuri transaksi keuangan mencurigakan perusahaan perikanan. PPATK dan KKP melakukan tiga kesepakatan, yakni pertukaran informasi, asistensi atau pendampingan dalam pengawasan terhadap perusahaan perikanan, dan pengembangan SDM (Kompas, 6 Januari 2015).

Kompleksnya persoalan nelayan, perlunya fokus memperbaiki nasib nelayan dengan pendekatan sistematis dan profesional. Beradasarkan data BPS, nilai tukar nelayan (NTN) khususnya perikanan tangkap turun 0,49 persen dari 106,72 pada Februari 2015. NTN merupakan angka yang membandingkan harga yang diterima (indeks harga) dengan harga yang harus dibayarkan (indeks beli) nelayan. Indeks harga menunjukkan perubahan harga paket komoditas yang dihasilkan nelayan melalui penangkapan ikan. Indeks beli menunjukkan perubahan harga paket komoditas yang harus dikeluarkan nelayan, baik untuk kepentingan hidup sehari-hari (konsumsi) maupun 
biaya melaut (produksi). Penurunan NTN menunjukkan taraf hidup kelompok nelayan menurun. Jika dibandingkan dengan kelompok nelayan budidaya, penurunan pada nelayan tangkap lebih besar. Jadi, memperbaiki nelayan nasib nelayan tangkap melalui revitalisasi sektor kelautan secara menyeluruh. Upaya penting membangkitkan sektor kelautan adalam membangun basis industri berikut mata rantainya, mulai dari bahan baku, pengolahan, pengemasan, hingga distribusi ekspor. Industri pengolahan ikan tak berkembang karena pasokan bahan baku ikan terbatas skala industrinya dan pasokan cenderung tak stabil. Membangkitkan sektir kelautan tak hanya menambah jumlah kapal pencari ikan, harus ada kerangka kebijakan industri maritim yang kuat (Prasetyantoko, 2015:15). Di sisi lain, kondisi perairan Laut Jawa di wilayah Jawa Tengah menurut Kasi Pengawasan dan Pengendalian Perikanan Dinas Perikanan dan Kelautan Jawa Tengah Kurniawan Priyo Anggoro, jumlah nelayan penangkap ikan melebihi kapasitas. Perairan hingga sekitar 5 mil $(9 \mathrm{~km})$ dari pantai tidak produktif, terutama di wilayah Kabupaten Demak dan Kendal. Jumlah nelayan tradisional di Pantura tahun 2003 sekitar 159.000 orang tahun 2013 diperkirakan masih 130.000 orang karena beralih profesi (Kompas, 14 April 2015).

\section{Kejahatan di Laut}

Di bidang maritim, pemerintah menampakkan keberaniannya bahwa kapal asing yang ilegal dan mencuri ikan di laut Indonesia ditenggelamkan. Penangkapan ikan ilegal tidak hanya dilakukan oleh kapal asing, tetapi juga oleh kapal dalam negeri. Beberapa modus pelanggaran kapal dalam negeri itu antara lain pelanggaran wilayah tangkap (fishing ground), memperkecil ukuran kapal besar menjadi di bawah 30 gros ton agar tidak perlu mengurus izin ke pusat dan menyetor penerimaan negara bukan pajak (PNBP). Hal ini menjadi momentum pemberantasan pencurian ikan yang sekian lama telah menguras kekayaan laut Indonesia. Penenggelaman dengan dalih Indonesia dirugikan Rp 300 triliun per tahun. Analisis Pattiradjawane, data kerugian tersebut untuk dicek ulang. Data Organisasi Pangan Dunia (FAO), produksi ikan Indonesia tercatat 5.420.247 ton pada tahun 2012, sedangkan data Dirjen Pengolahan dan Pemasaran 
Hasil Perikanan Kementerian Kelautan dan Perikanan pada tahun 2012 volume ekspor perikanan Indonesia tercatat 1.159.349 ton, selisihnya 4.260 .898 ton lebih besar data dari Dirjen. Bila harga ikan diasumsikan Rp 15.000 per kg, data FAO menunjukkan penerimaan negara mencapai Rp 81,303 triliun. Dari angka ini, diragukan bahwa potensi kerugian Indonesia Rp 300 triliun. Keraguan pun terjadi bila memerhatikan selisih data FAO dan Kementerian Kelautan yang mencapai 4,26 juta ton ikan dikonsumsi di dalam negeri karena tidak sesuai dengan konsumsi ikan per kapita Indonesia sebesar 31,5 kg (2014:8).

Pengawasan dan penegakan hukum yang melibatkan TNI AL, Polri, dan satuan kerja pengawasan Kementerian Kelautan dan Perikanan sepatutnya menjadi kekuatan untuk mengatasi kasus pencurian ikan dan penangkapan ikan ilegal. Badan Koordinasi Pengamanan Laut (Bakorkamla) karena dianggap kurang efektif digantikan oleh Badan Keamanan Laut (Bakamla) -yang memiliki kewenangan komando, keberadaannya berdasarkan Kepres Nomor 178 Tahun 2014- mendapatkan hibah 10 kapal patroli dari TNI AL berukuran panjang $57 \mathrm{~m}$ untuk menjaga keamanan laut Nusantara, di samping kapal dari lintas kementerian dan lembaga. Bakamla sesuai UU Nomor 32 Tahun 2014 tentang Kelautan, mengintegrasikan 13 komponen maritim yang memiliki kewenangan dalam keamanan maritim yakni TNI AL, kepolisian, KKP, imigrasi, dan bea cukai. Pengawasan dan kegiatan keamanan dan keselmatan laut melibatkan TNI $\mathrm{AL}$, polisi air (polair), dan pengawas sumber daya kelautan Kementerian KKP. Pengawasan di zona perairan 0-12 mil kewenangan aparat pengawasan KKP dan polair, zona 12-200 mil oleh aparat KKP, di atas zona 200 mil oleh TNI AL, penyidikan di bawah komanda Bakamla. Koordinasi antarkementerian untuk mengurangi ketidaksinkronan. Bakamla mengoperasikan 30 kapal pengawas, yang disiapkan TNI AL 10 kapal, KKP 3-5 kapal, dan Kemenko Kemaritiman 4 kapal (Kompas, 10 Januari 2015, hlm.18). Menurut Ponto, terdapat paradoks dalam pembentukan Bakamla, pertama, Bakamla dibentuk melalui Perpres Nomor 178 Tahun 2014 berdasarkan UU Nomor 32 Tahun 2014 tentang Kelautan. Sebagaimana diatur dalam UU Nomor 12 Tahun 2011 tentang hierarkhi pembentukan UU, maka perpres tidak boleh bertentangan dengan UU yang menjadi dasar pembentukannya 
dan perpres dibuat berdasarkan UU yang memerintahkannya. Pasal 2 Perpres Nomor 178 Tahun 2014 berbunyi, Bakamla bertanggung jawab kepada presiden melalui Menko Polhukam. Pasal 60 UU Nomor 32 Tahun 2014 menyatakan, Bakamla berkedudukan di bawah dan bertanggung jawab langsung kepada presiden melalui menteri yang mengoordinasinya. Siapa menteri yang berhak menggordinasikan Bakamla? UU Nomor 32 Tahun 2014 dibuat untuk dijadikan pedoman bagi menteri yang menyelenggarakan urusan pemerintahan di bidang kelautan dan perikanan yang berada di bawah koordinasi Menko Kementerian. Pola koordinasi yang mendua dan cenderung tidak jelas ini ujungnya akan menimbulkan benturan. Kedua, tugas Bakamla dalam Pasal 61: melakukan patroli keamanan dan keselamatan di wilayah perairan Indonesia dan wilayah yurisdikasi Indonesia. Kata 'patroli' artinya tidak ada tugas spesifik lain yang menjadi penting untuk segera dibentuk. Ketiga, Bakamla bukan penegak hukum, anggotanya bukan penyidik sehingga penegakan hukum atas pelanggaran terhadap UU Nomor 32 Tahun 2014 tentang Kelautan tidak mutlak harus dilakukan Bakamla, tapi dapat dilakukan satuan lain sepanjang diberikan tugas dan wewenang oleh UU. Wewenang Bakamla hanya melakukan pengejaran seketika; memberhentikan, memeriksa, menangkap, membawa, dan menyerahkan kapal kepda instansi terkait yang berwenang untuk pelaksanaan proses hukum lebih lanjut. Keempat, pada UU Nomor 32 Tahun 2014 tentang Kelautan, sama sekali tidak ditemukan ketentuan bahwa Bakamla harus dilengkapi dengan kapal. Artinya, bagaimana Bakamla bisa melaksanakan tugasnya, sementara dalam UU-nya dengan jelas dan pasti tidak dinyatakan harus dilengkapi dengan sarana bernama kapal. Hal ini sangat berbeda dengan KPLP dan pengawas Perikanan yang tugasnya dengan jelas dilengkapi kapal. Dengan demikian, pembentukan Bakamla merupakan paradoks (2015:6).

Kejahatan perikanan mulai dari perairan teritori sejauh 12 mil laut, perairan zona ekonomi eksklusif Indonesia (ZEEI) hingga sejauh 200 mil laut sampai laut lepas di atas 200 mil laut. Menteri Kelautan dan Perikanan Susi Pudjiastuti bersepakat dengan 6 negara tetangga untuk mengelola perikanan secara berkelanjutan dan bertanggung jawab. Lokasi dan potensi pencurian berada di sebagian wilayah perairan Laut Aru, Laut 
Arafuru, dan Laut Timor bagian timur. Potensi sumber daya ikan di wilayah ini mencapai 13 persen dari potensi sumber daya ikan laut nasional. Kontribusi udang dan ikan dari wilayah ini masing-masing mencapai 45 persen dan 20 persen terhadap produksi perikanan laut nasional. Kerugian akibat pencurian di 3 lokasi tersebut setiap tahun mencapai Rp 20 triliun. Adapun Badan Koordinasi Keamanan Laut Indonesia (Bakorkamla) dan Badan Pemeriksa Keuangan (BPK) memprediksi kerugian mencapai Rp 300 triliun per tahun. Adapun kekuatan armada patroli laut Indonesia terdiri TNI AL memiliki 72 kapal perang (Kapal Republik Indonesia), 18 korvet (kapal perang sedang dan cepat), 16 kapal patrol bersenjata misil/torpedo, dan 38 kapal patroli. Polisi Perairan (polair) memiliki 37 kapal terdiri 2 kapal patrol besar bersenjata, 5 kapal patroli bersenjata, 3 perahu patroli cepat, dan $27 \mathrm{kapal}$ patroli. Direktorat pengawasan sumber daya kelautan dan perikanan Kementerian Kelautan dan Perikanan memiliki 27 kapal terdiri kapal patrol ukuran sedang (60 meter) dan kapal patrol kecil. Kesatuan Penjaga Laut dan Pantai Ditjen Perhubungan Laut memiliki 28 kapal terdiri 4 kapal patroli jauh dan 24 kapal patrol kecil. Patroli Laut Ditjen Bea Cukai memiliki 65 kapal terdiri 15 perahu patroli cepat dan 50 kapal patroli kecil. Panglima TNI Jenderal Moeldoko mengatakan TNI AL siap menggerakkan 159 kapal dengan kebutuhan 350.000 kiloliter BBM per bulan. Kapal asing yang menangkap ikan di perairan Indonesia tanpa izin akan dikejar oleh Gugus Keamanan Laut (Guskamla) yang dimiliki oleh Komanda Armada Barat (Koarmabar) dan Koarmatim TNI AL, bukan wilayah kerja Gugus Tempur Laut (Guspurla) yang beroperasi tempur. Ketiganya di bawah TNI AL. Menurut Kapuspen TNI Mayjen Fuad Basya, bila menemukan kapal asing yang mencurigakan, dikejar dan digiring ke pelabuhan terdekat. Bila tidak mau, KRI (kapal TNI AL) merapat dan mengambil alih kendali. Bila kapal asing melawan dan menembak maka siap terjadi pertempuran. Bila kapal asing dapat digiring TNI ke pelabuhan terdekat, prosedur selanjutnya adalah penyidikan oleh aparat TNI AL. Setelah itu, persidangan dilakukan di pengadilan sipil, sesuai UU kapal asing yang disita atau prosedur lain. Kapal asing tidak bisa langsung ditenggelamkan di tengah laut. Prosedurnya, dibawa ke meja hukum. Tetapi, 
bila agresif, terjadi pertempuran (Kompas, 26 November 2014, hlm.1). Untuk menunjukkan keseriusan pemerintah menangani masalah pencurian ikan oleh kapal asing, Menteri Kelautan dan Perikanan (KKP) dengan KSAL Marsetio menandatangani nota kesepahaman di Mabes TNI AL untuk menegakkan hukum terhadap segala jenis pelanggaran, seperti penangkapan ikan illegal yang dilakukan kapal asing. Niat menenggelamkan pun akan dilakukan dengan dibom. Selama November 2014, sebanyak 6 kapal asing dari Thailand dan Vietnam ditangkap KKP karena melakukan penangkapan ikan illegal di wilayah Indonesia (Kompas, 2 Desember 2014). Polri mendukungnya dengan menyiapkan 670 unit kapalnya yang dapat menjangkau laut dalam dan 1.005 unti kapal menjangkau laut dangkal di sekitar pelabuhan. Untuk penindakan hukum, Polri menindak yang berada di perairan dengan batas maksimal 12 mil laut dari darat. Penindakan bekerja sama dengan Kesatuan Penjaga Laut dan Pantai (KPLP) (Suara Merdeka, 3 Desember 2014).

Sebanyak 3 kapal asal Vietnam ditarik dari Pelabuhan Tarempa ke arah barat hingga kurang lebih berjarak 1,6 km dari Pulau Tarempa. Kapal dijajarkan dalam jarak 200 m setiap kapal. Empat KRI dan kapal lainnya mengelilingi kapal asing itu. Setelah semua pada posisinya, kapal patroli dikirim untuk menjemput semua awak kapal nelayan kemudian dinaikkan ke kapal KRI Barakuda. Untuk memastikan kapal sudah kosong, sejumlah anggota TNI dikirim untuk mengecek. Lalu dikirim kapal komando Pasukan Katak (Paskas) TNI AL untuk memasang peledak di kapal. Setelah dipasang, di udara melintas pesawat milik TNI AU. Kemudian kapal diledakkan pertama sekitar pukul 10.45 Wib dan disusul ledakan berikutnya. ABK asing itu menyaksikan dari dek helikopter KRI Barakuda sambil duduk. Kapal ditangkap di utara Pulau Tarenpa, Anambas, Kepulauan Riau, awal November 2014. Kapal Mesin dengan nomor lambung KG 90433 TS/ATS 006 dengan nahkoda Nguyen Duy Khanh dan berawak an Thanh Son erawak 4 orang, dan KM bernomor lambung KG 94266/ATS 012 dengan nahkoda Nguyen Duc Van dan Berawak 19 orang. Awak KRI Imam Bonjol yang menangkap kapal itu tidak menemukan dokumen apa pun di 3 kapal asing. Di pangkalan, pemeriksaan dilanjutkan oleh penyidik TNI AL, selanjutnya kasus itu diserahkan ke Kejaksaan Negeri Tarempa. 
Peledakan juga dilakukan oleh Komando Pasukan Katak TNI AL Kapal Republik Indonesia (KRI) Sultan Hasanudin, KRI Todak, KRI Suteja Senaputra, dan KRI Barakuda pada Jumat 5 Desember 2014 di Laut Natuna, Kepulauan Riau. Dalam setahun, Armabar melakukan 12 kali operasi penegakan hukum dan kedaulatan laut. Selama 2014, Armabar menangkap 78 kapal asing yang melakukan pelanggaran di Indonesia. Menurut Pangarmabar Laksamana Muda Widodo, peledakan agar menimbulkan efek jera dan peledakan tidak melanggar hukum. Semua berdasarkan prosedur dan dilakukan secara manusiawi. Di pesisir pantai Desa Kiyama, Melongwane Timur, Kepulauan Talaud, Sulawesi Utara, pukul 15.00 Wita 4 Desember 2014 polisi membakar 3 kapal nelayan asal Filipina dan mendeportasi awak kapal. Pembakaran setelah berkoordinasi dengan Konjen Filipina di Manado (Suara Merdeka, 8 Desember 2014).

Dalam UU Nomor 45 tentang Perikanan, Pasal 69 (4) kapal pengawasan perikanan dapat melakukan tindakan khusus berupa pembakaran dan/atau penenggelaman kapal perikanan yang berbendera asing berdasarkan bukti permulaan yang cukup. Bukti permulaan berupa cukup bukti pencurian ikan, tak memiliki surat izin usaha penangkapan ikan (SIPI), tak memiliki surat izin kapal pengangkut ikan (SIKPI) atau memalsukan dokumen perizinan, anak buah kapal merupakan WNA dan penangkapan ikan melanggar wilayah penangkapan ikan yang telah ditentukan, kapal melakukan manuver membahayakan, nahkoha/ABK melakukan perlawanan. Sebelum dieksekusi, langkah awal yang dilakukan berupa mengevaluasi ABK, inventarisasi seluruh perlengkapan dan peralatan kapal, mengamankan dokumen, menyisihkan ikan sebagai barang bukti, dan menenggelamkannya. Pencurian ikan oleh kapal asing di perairan Indonesia dikategorikan kejahatan luar biasa karena pelanggaran kedaulatan yang membahayakan kedamaian, ketertiban, dan keamanan nasional.

Jumlah kapal asing yang ditangkap sebanyak 147 sepanjang 2014. Prosedur hukum berupa proses hukum, eksekusi (penenggelaman atau dilelang) hingga 8 Desember 2014 ada 33 kapal asing yang disita di Pontianak melalui proses pengadilan, sudah inkrah, dan menunggu eksekusi penenggelaman. Pada 5 Desember 2014: 3 kapal ikan berbendea Vietnam di perairan 
Tarempe, Anambas, Kepulauan Riau. Pada 21 Desember 2014 terdapat 2 kapal berbendera Papua Niugini di perairan Ambon, Maluku. Jumlah kapal asing yang terpantau dari system monitoring kapal terdapat 933 kapal sebelum larangan kapal asing diberlakukan pada 25 Oktober 2014, 164 kapal pada akhir November, dan 138 kapal pada 13 Desember 2014 (Kompas, 26 Desember 2014). Aparat Kementerian Kelautan dan Perikanan bersama TNI AL menangkap kapal besar MV Hai Fa berbendera Panama milik agen PT Anthartica Segara Lines berawal 23 orang asal Tiongkok dengan bobot 4.306 gros ton mengangkut ikan dari Avona menuju Wanam karena tak memiliki surat layak operasi. Kapal mengangkut ikan dan udang beku $900.702 \mathrm{~kg}$ terdiri ikan $800.658 \mathrm{~kg}$ dan udang beku $100.044 \mathrm{~kg}$. Kapal bersandar di Pelabuhan Umum Wanam, Kabupaten Merauke, Papua, Sabtu 26 Desember 2014, pukul 12.00 WIT. Kapal dikawal menuju Lantamal IX Ambon pada 1 Januari 2015. Kapal pengawas KKP pada 9 Januari 2015 menangkap dan menahan tiga kapal pengangkut ikan Indonesia yakni KM Jaya Bali Bersaudara 92 berukuran 44 GT, KM TIP 102 (86 GT), dan KM Nusantara VIII (172 GT) yang diduga melakukan praktik alih muatan kapal. Ketiga kapal mendaratkan tangkapan di daerah dermaga pelabuhan PT Bintang Mandiri Bersaudara tapi tak dilaporkan ke pengawas perikanan (Kompas, 13 Januari 2015). KKP, Polri, dan TNI AL mengamankan 142 ABK dan menenggelamkan 41 kapal ikan asing dengan dinamit daya ledak rendah hasil operasi Januari-April 2015, 5 dari Vietnam, 2 dari Tahialnd, 1 dari Tiongkok, dan 11 dari Filipina secara serentak karena illegal fishing terdiri 6 ditenggelamkan di perairan Pontianak Kalbar, 11 di Bitung Sulut, 1 di Belawan Sumut, dan 1 di Aceh, 22 di Ranai Kepulauan Riau. Tujuan penenggelaman untuk mengembalikan kedaulatan Negara atas kekayaan laut. Hal ini dilaksanakan pada peringatan Hari Kebangkitan Nasional 20 Mei 2015 (Kompas dan Suara Merdeka, 21 Mei 2015).

Problem yang dihadapi petugas di tengah laut dalam melakukan penindakan kapal yang melakukan pelanggaran menurut Panglima TNI Jenderal Moeldoko (1) besarnya biaya pengoperasian satu kapal patroli membutuhkan dana Rp 900 juta per jam yang terbanyak untuk BBM, (2) kapal asing pencuri ikan memiliki teknologi yang lebih canggih daripada milik TNI 
AL, misalnya radar lebih modern dengan kecepatan lebih tinggi. Sebagaimana posisi radar dan pelabuhan berada di Ambon. Untuk mencapai laut Aru, kapal patrol membutuhkan waktu 2-3 hari, dan minimnya jumlah kapal yang dimiliki Indonesia. Mengantisipasinya, dibutuhkan pesawat yang berkecepatan tinggi dan mampu mendarat di perairan atau jet ampibi (Jawa Pos, 26 Desember 2014).

\section{Ayat Al-Quran tentang Maritim}

Pesan Al-Quran tentang maritim di antaranya tertuang dalam an-Nisa: 97, al-Furqon: 53 Allah membiarkan dua laut mengalir (berdampingan) yakni tawar lagi segar dengan asin nanpahit, keduanya terdapat dinding dan batas penghalang, ar-Rahman:19-20 Allah membiarkan dua lautan mengalir dan bertemu, keduanya tak dilampaui. Pesan tersebut dibuktikan Mr. Jacques Yves Costeau, ahli Oseanografi dan penyelam asal Perancis ketika menyelam ia melihat dan merasakan kumpulan mata air tawar, segar, dan sedap rasanya karena tak bercampur/tak melebur dengan air laut sekelilingnya, seolah-olah terdapat dinding atau membran yang yang membatasi keduanya. Di Cenote Angelitan terdapat dua gua yang berhubungan dengan laut. Jika diselami sedalam 30 meter terasa airnya segar, jika diselami lebih dalam lagi sampai 60 meter airnya menjadi asin. Juga ditemukan sebuah sungai di dasarnya lengkap dengan pohon dan dedaunan. Selat Boshphorus yang aliran airnya dari Mediterania hingga Laut Hitam ditemukan sungai di bawah laut yang airnya mengalir membentuk alur dan genangan yang dalam. Menurut Dan Parsons, tim peneliti dari Sekolah Tinggi Ilmu Bumi dan Lingkungan, Universitas Leeds bahwa kepadatan air di sungai bawah laut lebih padat dari air laut di sekitarnya karena salinitas yang lebih tinggi dan membawa banyak sedimentasi. Sungai mengalir airnya dari beting laut dan keluar melalui daratan abisal, sebagaimana sungai di daratan. Daratan abisal di laut menyerupai gurun pasir, bedanya daratan air ini bisa menyediakan nutrisi dan bahan yang dibutuhkan untuk makhluk yang hidup di dalamnya. Parson menemukan sungai bawah tanah di dasar Laut Hitam mengalir dengan kecepatan sekitar 4 mil per jam yang mengalirkan 22 ribu meter kubik air tawar per detik, 10 kali lebih besar dari sungai terbesar di Eropa, Rhine. Sungai di bawah laut mengalir 
hanya sekitar 37 mil hingga mencapai tepi beting laut sebelum menghilang ke laut dalam (Suara Merdeka, 3 Oktober 2010). Pesan Ali Imran:137 Sesungguhnya telah berlalu sebelum kamu hukuman Allah berupa malapetaka, bencana yang ditimpakan pada pendusta terhadap Rasul-Nya. Berjalanlah di muka bumi dan perhatikanlah akibat pendusta Rasul-Nya. Al-An'am:11 berjalanlah di muka bumi, perhatikan dampak pendusta. ArRum:9 apakah mereka tak melakukan perjalanan di muka bumi dan memperhatikan akibat orang sebelummu?

Dengan demikian Al-Quran menandaskan bahwa perairan/laut dapat dijadikan telaah lebih mendalam untuk kesejahteraan warga bangsa.

\section{Simpulan}

Catatan bagi pemerintahan Jokowi, hingga akhir 2014, semangat membangun maritim, menurut sejarawan JJ Rizal perlu menggali nilai-nilai kemaritiman yang tidak hanya aspek ekonomi. Aspek laut sebagai dunia budaya dan jaringan kultural perlu digali. Dunia maritim Nusantara yang besar telah dilupakan dalam periode panjang karena kedatangan kolonial. Nilai maritim berupa kehidupan masyarakat Nusantara dengan laut dan laut bisa menjadi 'bazar kultural' bukan unit ekonomi saja. Ditambahkan oleh sejarawan LIPI, Hilmar Farid, wacana kemaritiman tidak hanya di kalangan elite politik tapi harus diperluas sebagai kesadaran publik. Pendidikan perlu lebih mengenalkan lagi bahwa Indonesia sebagai negara maritim (Kompas, 31 Desember 2014). Pada dasawarsa kedua abad ke21 geopolitik Asia mencari bentuk baru dalam penataan politik dalam dan luar negeri. Indonesia dengan gagasan Poros Maritim Global sebagai simbol teritorial dan kebijakan luar negerinya.

Merespon besarnya sumber kehidupan warga dari laut, dalam lima tahun ke depan, Menteri Pendidikan dan Kebudayaan Anies Baswedan berniat menambah program studi atau materi ajar yang terkait dengan kemaritiman, antara lain bidang kelautan, perikanan, dan perkapalan yang diberikan dalam bentuk pendidikan vokasi dengan menekankan kemampuan teknis atau keterampilan. Masalahnya, menurut menteri, orientasi pemerintah pada pembangunan maritim tetapi masyarakat belum memiliki orientasi yang sama. Hal ini dapat 
dilihat dari materi ajar yang banyak menggunakan contoh nonkemaritiman. Hal ini dinyatakan Mendikbud dalam Konferensi Internasional Penyelarasan Pendidikan dan Dunia Kerja di Bogor Selasa, 18 November 2014. Direktur Pembinaan Sekolah Menengah Kejuruan (SMK) Kemendikbud menambahkan, pihaknya akan merevitalisasi semua SMK yang bergerak di bidang kemaritiman mulai tahun 2015 dengan melengkapi sarana prasarana pembelajaran dan praktik, peningkatan kualitas kompetensi guru, dan proses pembelajaran yang menggandeng industri kemaritiman melalui teaching factory, sebagaimana telah dilakukan di bidang otomotif. Problemnya, terbatasnya jumlah guru yang memiliki kompetensi yang dipersyaratkan, yakni harus memiliki pengalaman praktik lapangan. Data Kemendikbud, terdapat 140 SMK yang bergerak di bidang kemaritiman dengan beasiswa, meski minat pengguna jasa rendah. Meruahnya sumber daya laut tapi dimanfaatkan oleh pencurian kapal asing setiap tahun negara menderita kerugian mencapai Rp 300 triliun. Di sisi lain, penerimaan negara dari sektor kelautan hanya Rp 300 miliar tiap tahun (Kompas, 19 November 2014).

Dengan demikian, tatakelola maritim dengan baik dan bijaksana menjadi hal mendasar agar sumber daya kelautan dapat meningkatkan kesejahteraan rakyat. 
Moh. Rosyid

\section{DAFTAR PUSTAKA}

Husen, Muhamad. Berdayakan Akuakultur. Kompas, 12 Januari 2015.

Pramodhawardani, Jaleswari. TNI dan Kompleksitas Isu Perbatasan. Kompas, 5 Oktober 2010.

Pattiradjawane, Rene L. Statistik Kebijakan Luar Negeri RI. Kompas, 26 November 2014.

Ponto, Soleman B. Paradoks Bakamla. Kompas, 11 Februari 2015.

Prasetyantoko, A. Restrukturisasi Industri Kelautan. Kompas, 13 April 2015.

Rosyid, Moh. Toleran dalam Berderma. Opini dalam Koran Muria, Jumat 2 Januari 2015.

Satria, Arif. Jangan Lagi Ada Perikanan Ilegal. Kompas, 13 Desember 2014.

Suprayoga, Joko. Menimbang Lagi Jaring Cantrang, Suara Merdeka, 27 Desember 2014.

Syahailatua, Augy. Mengawal Laut Arafura. Kompas, 17 Januari 2015. 
